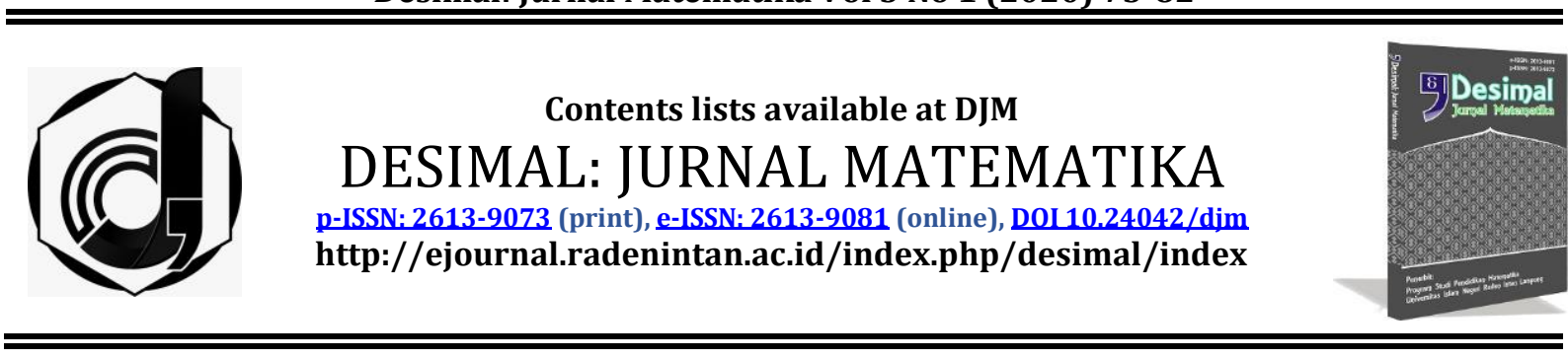

\title{
Application of Discovery Learning Method in Mathematical Proof of Students in Trigonometry
}

\author{
Windia Hadi*, Ayu Faradillah \\ University of Muhammadiyah Prof. DR. HAMKA, Indonesia
}

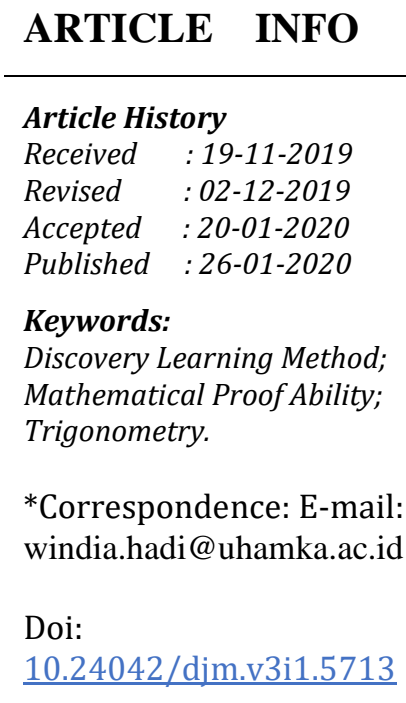

\begin{abstract}
Trigonometry is a part of mathematics in learning that is related to angles. The purpose of this study was to determine the effect of the application of discovery learning methods in students' mathematical proof ability on trigonometry. The research method used in this study is quasi-experimental. The population in this study was the second semester of $2016 / 2017$. The sample was 66 people who were determined by purposive sampling. The instrument used in this study was a mathematically proof ability test. Analysis of the data used is the t-test. The results of this study are (1) based on an average score of mathematical proof ability The student's mathematical proof ability in applying the Discovery Learning Method to trigonometry is not higher than the mathematical proof ability of students who do not use the discovery method (2) there is no significant influence in the application of learning methods Discovery in students' mathematical proofs on trigonometry.
\end{abstract}

http://ejournal.radenintan.ac.id/index.php/desimal/index

\section{INTRODUCTION}

Trigonometry comes from the Greek trigon, which is three angles and metro, namely measurement. Trigonometry is a branch of mathematics that deals with the edges of triangles and also deals with geometry. Trigonometry is the basis for the comparison of acute angle trigonometry, which developed into the concept of non-acute angles - solving problems related to trigonometry considered very difficult so it requires a more in-depth understanding of studying trigonometry, especially about geometry.

A Mathematics Education student must have the mathematical proof ability in solving a mathematical problem. Mathematical proof ability is essential to be possessed by a Mathematics Education student more accurately. They will become teacher candidates for their students - the proof ability, which is a fundamental ability in understanding trigonometry. Students are said to have the mathematical proof ability if students 
can validate or criticize evidence and construct evidence related to the types of evidence that often arise.

One of the subjects that require students' skills in the mathematical proof is trigonometry. Trigonometry is one of the compulsory subjects that must be taken by students of mathematics education study programs as teacher candidates. It is said to be a compulsory subject because the concept of material becomes the basic concept that must teach for the next level of topics such as calculus 1.2 and so on, as well as the foundation in High School. The many trigonometric formulas that cause this material are demanding for high school students to deal with in examinations. Facts in the field show trigonometry is not a natural material for students. Not only students, but students also experienced difficulties when developing evidence on the content at the University (Minggi, Paduppai, \& Assagaf, 2016)

One reason for the challenge of developing mathematical proof ability, according to Demir ((Ilmi \& Rosyidi, 2016) it is not easy for students to build understanding based on trigonometric relationships. In the trigonometry course, there are still many students who are less able to make evidence between trigonometric formulas (Himmi, 2017). The analysis shows that the majority of the sample teacher candidates do not understand quadrants or radians, similar to those found by (Tuna \& Kacar, 2012), namely mathematics teacher candidates in Turkey have a misconception about trigonometry.

The difficulties experienced by prospective teachers in research and middle-level students who complain about the problem of trigonometry solving is a cohesive alignment in trigonometric problems. Prospective teachers are fully qualified individuals who, or will teach mathematics at the secondary level. Therefore, misconceptions, procedural approaches, and underdeveloped visualization skills conveyed to their students. If the findings of this study are not addressed, the problems identified in trigonometry will likely continue (Walsh, Fitzmaurice, \& O'Donoghue, 2017). Problem is the focus of research on whether there is the effect of discovery learning methods in the ability of mathematical proof in trigonometry.

Also, one of the materials in trigonometry at the high school level is to prove the identity of trigonometry. Students cannot find/prove the ways/strategies used in solving trigonometric problems (Ilmi \& Rosyidi, 2016).

Thus, the evidence related to trigonometry material becomes one of the elements that are difficult for students. Research conducted by (Jingga, Mardiyana, \& Setiawan, 2017) done with high school students there are still many shortcomings in understanding the concept of trigonometry and the mistakes made by all groups are the mistakes made describing each of the trigonometric comparison relationships resulting in calculations to be complicated, the cause is the inability of students to determine the relationship between formulas on trigonometric identities, besides that Medium and low group errors are students not thinking about other ideas, lack understanding of the concept of arithmetic operations, lack of skill in doing algebraic manipulation, students' inability to determine the relationship between formulas on trigonometric identities and misinterpreting writing.

Results based on the above problems, the right learning method to improve mathematical proof ability is the discovery learning method. Discovery learning method is a learning 
Desimal, 3 (1), 2020 - 75

Windia Hadi*, Ayu Faradillah

method that provides an opportunity for students to construct their knowledge by discovering for themselves a concept, principle, procedure, algorithm and the like that has been learned with the experience obtained and not through notification but its discovery either partially or entirely with a trial error, experiment, explore and guess (Fajri, Ikhsan, \& Subianto, 2018). Based on research (Hadi, 2016) Discovery methods can improve students' mathematical abilities. Thus this study, the author intends to examine "the application of Discovery learning methods in the Mathematical Proof of Student Ability in Trigonometry." Based on the background that has described, then the problem can be formulated as follows: (1) Is the mathematical proof ability of students in applying Discovery learning methods on trigonometry higher than the mathematical proof ability of students who do not use Discovery teaching methods? (2) whether there is a significant influence in the application of Discovery learning methods in students' mathematical proof ability on trigonometry.

\section{RESEARCH METHODS}

The approach used in this study uses a quantitative approach. The mathematical proof ability of students of mathematics education study program will explore how the mathematical proofing ability of students after being given the discovery learning method treatment and those not treated in the form of discovery learning method.

Research conducted in this study is a quasi-experimental study. In this study, subjects not randomly grouped, but researchers accepted the subject's condition as it is, with the Posttest-Only Control Design (Sugiyono, 2010). Then the research design can be written as follows.

Table 1. Posstest-Only Control Design

\begin{tabular}{lll}
\hline Class & treatment & Posttest \\
Experimental & $\mathrm{X}$ & 0 \\
Control & - & - \\
\hline
\end{tabular}

The population in this study were all semester 2 Mathematics Education study program students, 2016/2017 school year consisting of six classes. Meanwhile, the samples in this study are two classes of semester two students. So, the two types that have to examples are 33 students as the experimental class and 33 students as the control class. The total sample was 66 students. They are taking the sample by purposive sampling.

Data collection techniques used in this study is to carry out the test. The test conducted to measure the mathematical proof ability of the experimental class and control class students.

The test questions consist of 5 indicators of mathematical proof ability, namely: The first indicator criticizes the proof by adding, subtracting or rearranging a mathematical proof, the second indicator reads mathematical proof, the third indicator directly proving, the fourth indicator arranges the evidence and the fifth indicator is validating the form of evidence. Data analysis can be seen in Figure 1 as follows. 
Desimal, 3 (1), 2020 - 76

Windia Hadi*, Ayu Faradillah

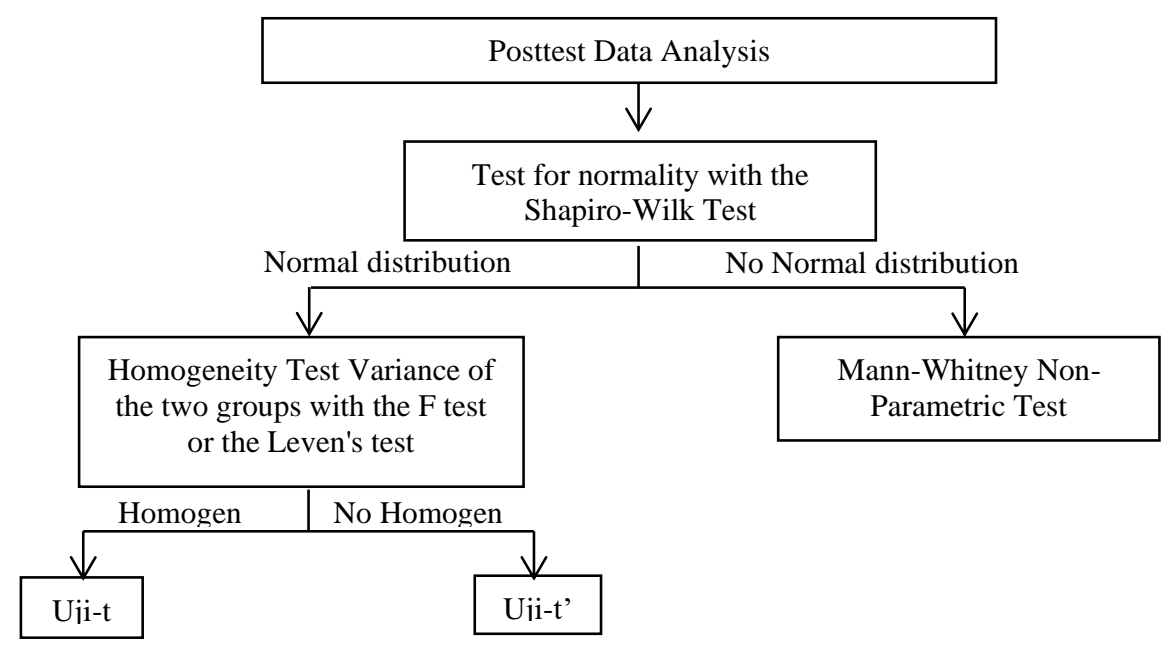

Figure 1. Data Analysis Procedure Chart

\section{RESULTS AND DISCUSSION}

The results of the research data obtained an average score of UHAMKA students 'mathematical proof ability that applied the Discovery learning method on trigonometry was 12.39 with a standard deviation of 4.93, while the average rating of UHAMKA students' mathematical proof abilities that did not use the discovery method on trigonometry was 13.12 with a standard deviation of 2.91 .

Based on the calculation of the average experimental class with the control class obtained thitung $=-0.72$ with a significance level of 0.05 and a degree of freedom $(d k)$ of 64 earned $t_{\text {tabel }}$ $=1,66$. When compared, it can be seen the value $t_{\text {hitung }}=-0,72<1,66=t_{\text {tabel }}$, then $H_{0}$ is accepted.

The acceptance of $H 0$ concluded that the Students' Mathematical Proof Ability in applying the Discovery Learning
Method to trigonometry was not higher than the mathematical proofing ability of students who did not use the discovery learning method. Thus, there is no significant effect of discovery learning methods on the mathematical proof ability of trigonometry.

The following is an analysis of the students' answers from each indicator in the item about the mathematical proof ability of UHAMKA students.

Indicators criticize proof by adding,
subtracting or rearranging a
mathematical proof
In this study, what measured in indicator one is the ability of students to criticize the proof by adding, subtracting, or rearranging a mathematical proof. The items that use this indicator are item 1. The following is one of the students' answers from the accurate confirmation ability test number 1 that matches sign one in the experimental class. 
Desimal, 3 (1), 2020 - 77

Windia Hadi*, Ayu Faradillah

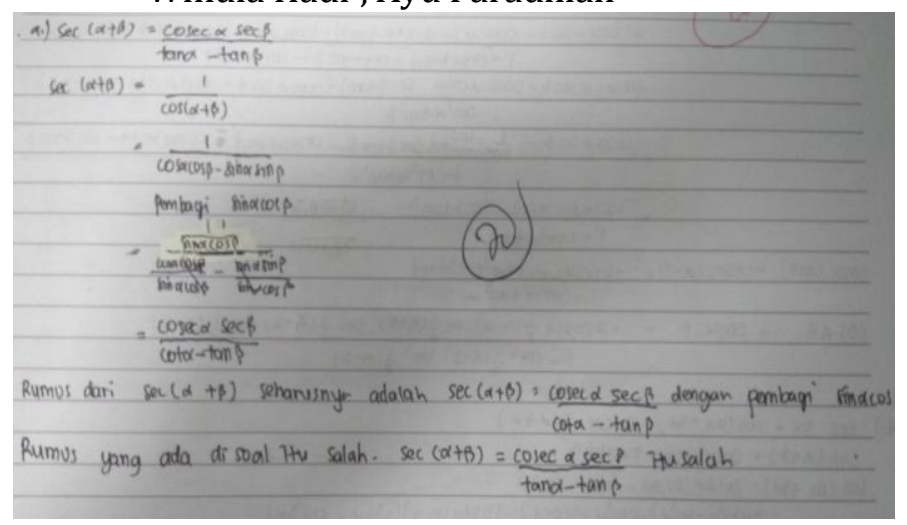

Figure 2. Correct Answer Item No. 1 Experiment Class

From the results of student answer number 1 in Figure 2, it has been that experimental students can criticize the evidence in problem number 1 . Starting from students prove correctly and criticize the proof for problem number 1 . In the innovative class, 26 students can describe very well the number problems 1 , and some students are wrong in terms of proving, what is meant by students is not careful enough in writing proof. By research (Himmi, 2017) revealed that many students were less able to do tests between trigonometric formulas. There is one student who gets a score between 1 , there are three students who get a score of 2, there are two students who get a score of 3 . and there is one person who receives a score of 0 . The rest of the students managed to answer the indicator questions one well that is getting a score of 4 . In class In the control, six students got a score of 3 and 1 student who got a rating of 2 . It is seen that similarly, seven students lacked depth to answer the question instrument on the first indicator; the difference is the lowest score in the experimental class and the control class. Seen from the first indicator score in the lowest innovative level 0 and the lowest score control class is 2 .

Based on the analysis of student answers, it appears that the experimental class is superior to the control class in which many innovative class students answer correctly than the control class students. So based on the analysis of the answer, the experimental type is better than the control class. That is means that the use of the discovery method affects the mathematical proof ability of students of Mathematics Education Study Program in UHAMKA.

\section{The second indicator reads mathematical proof}

What is measured in the second indicator is the ability of proof to read the mathematical proof. Below is an example of an experimental class student learning mathematically correct tests. 
Desimal, 3 (1), 2020 - 78

Windia Hadi*, Ayu Faradillah

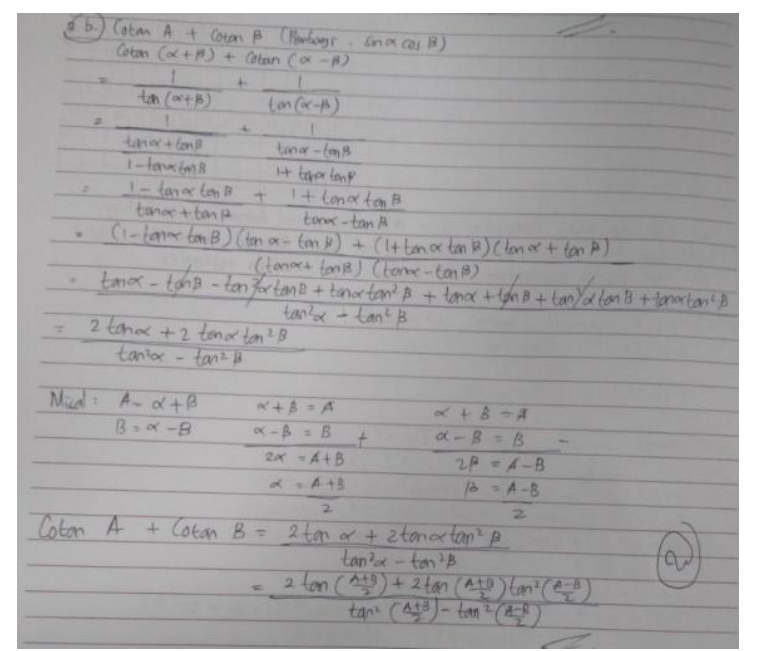

Figure 3. Correct Answer Item No. 2 Experiment Class

From the results of student answer number 2, in Figure 3., it can be seen that experimental students can read mathematical proofs well. That can see from the way students can describe evidence well. That is consistent with the findings from (Dereu, 2019) that moving towards a measurement-oriented and constructivist approach can provide students with a deeper understanding of trigonometry.

\section{The third indicator is direct proof}

The third indicator is direct proof. The following are the answers of students in the third indicator. This third indicator describes how students in proving trigonometric formulas with different versions whose results will be the same.

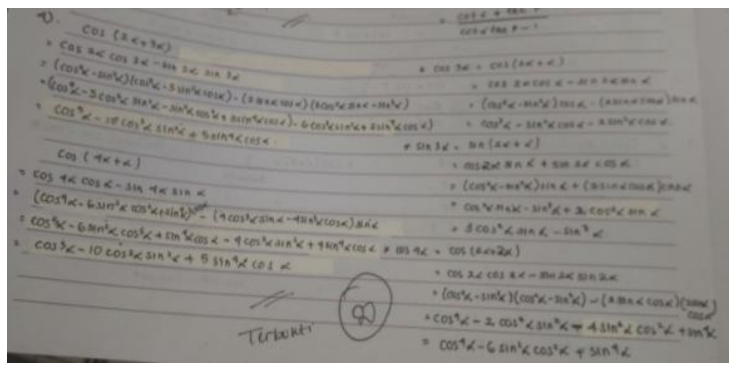

Figure 4. Correct Answer Item No. 3 Experiment Class

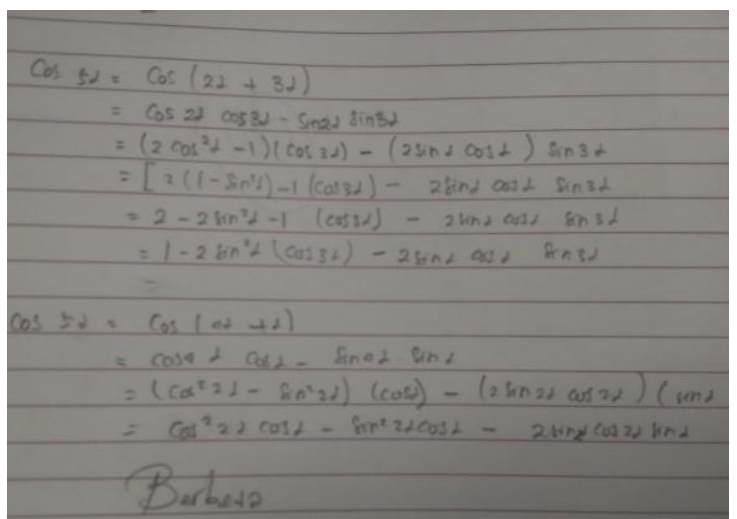

Figure 5. Wrong Answer Item No. 3 of the Control class 
Desimal, 3 (1), 2020 - 79

Windia Hadi*, Ayu Faradillah

Figure 4 and 5 is an example of the completion of the third indicator, namely direct proof, where students first describe the results of various versions based on trigonometric rules. The results should be the same if spelled out in several versions; the above is a real and false example indirectly proving trigonometric material.

In the experimental class, 11 students were able to prove right away directly without the slightest error, whereas in the control class, only five students were able to answer correctly, with a score of 4. Meanwhile, students who received a score of 3 in the experimental category were five students; for the control class, 15 students get a score of 3 . Error in rating 3 is the student can describe the rules correctly, but the student is wrong in answering that is the student proves that the formula is different in each version, so this is what reduces the student's score while score 2 in the experimental class were eight students, while in the control class there were six students.

The student's mistake in proving is that the student is not careful in describing the rules of the formula directly. Four students in the experimental class received a score of 1 and in the control class, there were two students. The innovative and control level contained five students who could not prove the third indicator directly. That is following the findings of (Jingga et al., 2017) that the mistakes made describe each relation of trigonometric comparisons resulting in calculations to be complicated; the cause is the inability of students to determine the relationship between formulas on trigonometric identities.

Based on the analysis of the students' answers to the third indicator, it appears that the experimental class is superior to the control class, where more preparatory courses can complete the third indicator very well even though only $33 \%$. That proves that the discovery method can further improve mathematical proof ability based on the analysis of student answers.

\section{The fourth indicator constitutes proof}

The fourth indicator is composing evidence. Arranging the evidence referred to in the proof ability indicator is the ability of students to find the angle with known trigonometric equations with zero value, with the previous sign the student has been able to prove directly followed by the student being able to compile the evidence from the information that has been found in advance so that the student can collect proof well.

Below is a picture of the correct student answers in the experimental class and the control class.

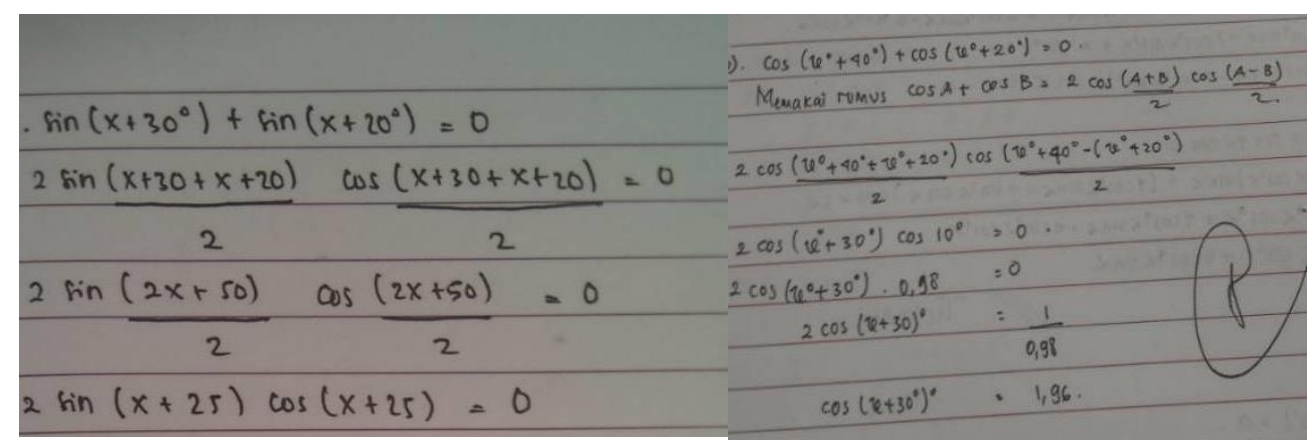

Figure 6. Wrong Answer item No. 4 Control class 
Based on Figure 6, it can how students have not been able to arrange evidence well; students can only derive from the informed problem formula. However, it is still wrong to operate algebra in trigonometric rules. That is by the findings (Hadi \& Faradillah, 2019) that in serving algebra students still have difficulty understanding concepts. In the experimental class, ten students were able to arrange the evidence correctly, while in the control class, there were only two students who were able to arrange the evidence correctly and got a score of 4 . In the experimental and control level, there was only one student who got a rating of 3 . in the trial and control class there were three people and 22 people in sequence who got a score of 2 . In the experimental type, 15 students and four students in the control class got a score of 1 , while those who got a score of 0 there were four innovative class students and two control class students. It is clear that for indicators compiling proof, students still have difficulty answering this fourth indicator.

Based on the results of the analysis of the answers to the fourth indicator, that the experimental class outperformed the fourth indicator even though there were still many students who were wrong or incorrect in answering the fourth indicator instrument. The innovative level is higher than the control class.

\section{The fifth indicator validates the form of proof}

The fifth indicator is validating the form of proof; the purpose of validating here is students can verify the structure of trigonometric inequality with the evidence that has known previously. Students can confirm the form of evidence in the way of results that have found; if students can validate the proof well, it means students can have mathematical proof ability well. Below is a picture of the effects of student answers invalidating the form of evidence on the fifth indicator.

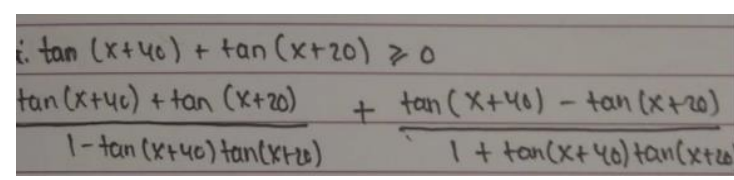

Figure 7. Wrong Answer item No. 5 experimental class

Based on Figure 7, it found that students are still not able to validate correctly, on the answer sheet the students only describe the trigonometry rules that are known beforehand, if students are not able to prove from the available information means that students cannot validate the form of the problem is true or false, so the indicators The fifth is a combination of the first to fourth indicators and ends by confirming the results that have been obtained by students. That is consistent with the findings (Minggi et al., 2016) states that there are two categories of difficulties for students in proving, namely the lack of understanding of mathematical evidence and the lack of knowledge of concepts and principles in mathematics

In the experimental class only four students were able to validate the form of proof well, while in the control class, there was one student who could verify the type of research. In the experimental category, there is one student, and two control class students who get a score of 3 , students who get a score of 3 are capable students who have been able to prove it's just wrong invalidating the form of proof. In the experimental class of 2 students and 21 control class students who got a score of 2 , the student's error in answering the fifth indicator problem was that the student was wrong in proving so that even the results would be validated even wrong. In the experimental class, there were 18 students and two control class students who got a score of 1 , and in the innovative type, there were eight students and seven control class students who were unable to answer the fifth indicator.

Based on the analysis of students' answers to the fifth indicator that students still have difficulty validating the form of 
evidence, it how the lowest score obtained by many experimental and control class students. Based on the analysis, it appears that the control class is superior to the innovative level; it can see how the answer with a score of 3 is more, even though the results are also incorrect and there are still errors.

Based on the first to fifth indicators, it is clear that students still have difficulty in terms of mathematical proof ability so that this causes no effect of discovery methods on mathematical proof ability. Analysis of the answers showed that the experimental class was better than the control class, as seen in how students were able to get a higher score than the control class. Not too prominent differences that also influence the results of statistical analysis in the calculation of hypothesis testing. That also causes the discovery method not to have a significant influence on increasing the mathematical proof ability. Also, seen from the average results of the experimental class and the control class, even the control class is slightly superior to the innovative level, this also causes the discovery method to have no significant effect on mathematical proof ability.

The thing that causes the average experimental class is less than the control class is the mathematical proof ability of preliminary class students who are unable to complete all instruments of mathematical proofing ability; the student does not answer the instrument question with his knowledge, there is no writing described by the student. Students are emptying all the answers of the instruments that have been given by researchers. That causes the average experimental class to be less than the average control class. So the control class is superior to the innovative level based on average results.

\section{CONCLUSION AND SUGGESTION}

Based on the results of the study, it can conclude that the average score of students' mathematical proof ability by using discovery learning methods is no better than those not using discovery learning methods.

Based on the results of research using the t-test, it can conclude that there is no significant effect of mathematical proof ability that uses discovery learning methods with those that do not use discovery learning methods.

\section{REFERENCES}

Dereu, E. (2019). Student 's Self Discovery of Right Triangle Trigonometry.

Fajri, N., Ikhsan, M., \& Subianto, M. (2018). Mathematical reasoning abilities of students through a model of discovery learning in senior high school. Proceedings of The 8th Annual International Conference (AIC) on Social Sciences, (2000), 123-132.

Hadi, W. (2016). Meningkatkan kemampuan penalaran siswa SMP melalui pembelajaran discovery dengan pendekatan saintifik (Studi kuasi eksperimen di salah satu SMP Jakarta Barat). Kalamatika, I(1), 93108.

Hadi, W., \& Faradillah, A. (2019). The Algebraic Thinking Process in Solving Hots Questions Reviewed from Student Achievement Motivation. AlJabar: Jurnla Pendidikan Matematika, 10(2), 327-337. https://doi.org/10.1017/CB097811 07415324.004

Himmi, N. (2017). Korelasi Self Efficacy Terhadap Kemampuan Penalaran Matematis Mahasiswa Semester Pendek Mata Kuliah Trigonometri Unrika T.a. 2016/2017. PYTHAGORAS: Jurnal Program Studi Pendidikan Matematika, 6(2), 143150.

https://doi.org/10.33373/pythagora s.v6i2.941

Ilmi, M. B., \& Rosyidi, A. H. (2016). MATHE dunesa. Jurnal Ilmiah Pendidikan Matematika, 1(5), 21-29. 
Desimal, 3 (1), 2020 - 82

Windia Hadi*, Ayu Faradillah

Jingga, A. A., Mardiyana, \& Setiawan, R. (2017). Analisis Kesalahan Siswa dalam Menyelesaikan Identitas Trigonometri pada Siswa Kelas X Semester 2 SMA Negeri 1 Kartasura Tahun Ajaran 2015/2016. Keywords in Qualitative Methods, 1(5), 48-62. https://doi.org/10.4135/97818492 09403.n73

Minggi, I., Paduppai, D., \& Assagaf, S. F. (2016). Penyebab Kesulitan Mahasiswa dalam Pembuktian Matematika. Jurnal Penelitian Pendidikan INSANI, 19(1), 18-2.

Tuna, A., \& Kacar, A. (2012). 1 ST CYPRUS INTERNATIONAL CONGRESS OF Full Text Book. Prospective Mathematics Teachers' Misconceptions About Trigonometry, 92-97.

Walsh, R., Fitzmaurice, 0., \& O'Donoghue, J. (2017). What Subject Matter Knowledge do second-level teachers need to know to teach trigonometry? An exploration and case study. Irish Educational Studies, 36(3), 273-306. https://doi.org/10.1080/03323315. 2017.1327361 